\title{
Assessment of soil $n$-alkane $\delta D$ and branched tetraether membrane lipid distributions as tools for paleoelevation reconstruction
}

\author{
F. Peterse ${ }^{1}$, M. T. J. van der Meer ${ }^{1}$, S. Schouten ${ }^{1}$, G. Jia ${ }^{2}$, J. Ossebaar ${ }^{3}$, J. Blokker ${ }^{1}$, and J. S. Sinninghe Damsté , $^{1,3}$ \\ ${ }^{1}$ Department of Marine Organic Biogeochemistry, NIOZ Royal Netherlands Institute for Sea Research, P.O. Box 59, \\ 1790 AB Den Burg, Texel, The Netherlands \\ ${ }^{2}$ State Key Laboratory of Organic Geochemistry, Guangzhou Institute of Geochemistry, Chinese Academy of Sciences, \\ Guangzhou 510640, China \\ ${ }^{3}$ Faculty of Geosciences, Utrecht University, P.O. Box 80021, 3508 TA Utrecht, The Netherlands
}

Received: 21 August 2009 - Published in Biogeosciences Discuss.: 1 September 2009

Revised: 26 November 2009 - Accepted: 27 November 2009 - Published: 3 December 2009

\begin{abstract}
O}$ values of pedogenic minerals forming from soil water are commonly used to reconstruct paleoelevation. To circumvent some of the disadvantages of this method, soil $n$-alkane $\delta D$ values were recently proposed as a new tool to reconstruct elevation changes, after showing that soil $n$ alkane $\delta D$ values track the altitude effect on precipitation $\delta D$ variations $\left(r^{2}=0.73\right.$ along Mt. Gongga, China). To verify the suitability of soil $n$-alkane $\delta D$ values as a paleoelevation proxy we measured the $\delta D$ of soil $n$-alkanes along Mt. Kilimanjaro (Tanzania). At midslope, soil $n$-alkane $\delta D$ values are possibly influenced by the present precipitation belt, causing D-depletion in precipitation, and hence in the soil $n$-alkanes. Consequently, soil $n$-alkane $\delta D$ values do not linearly relate with altitude $\left(r^{2}=0.03\right)$, suggesting that, in this case, they can not serve as an unambiguous proxy to infer past elevation changes. In contrast, it was recently shown that the MBT/CBT temperature proxy, which is based on the distribution of branched glycerol dialkyl glycerol tetraether (GDGT) membrane lipids, is linearly related with MAT, and thus altitude $\left(r^{2}=0.77\right)$, at Mt. Kilimanjaro. This suggests that this proxy may be more suitable for paleoelevation reconstruction for this region. However, application of the MBT/CBT proxy on the altitude gradient along Mt. Gongga showed that, although the MBT/CBT-derived temperature lapse rate $\left(-5.9^{\circ} \mathrm{C} / 1000 \mathrm{~m}\right)$ resembles the measured temperature lapse rate $\left(-6.0^{\circ} \mathrm{C} / 1000 \mathrm{~m}\right)$, there is a relatively large degree of scatter $\left(r^{2}=0.55\right)$. Our results thus show that both
\end{abstract}

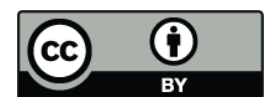

Correspondence to: F. Peterse (francien.peterse@nioz.nl) proxies can be subject to relatively large uncertainties in their assessment of past elevation changes, but that a combination of the soil $n$-alkane $\delta D$ and MBT/CBT proxies can likely result in a more reliable assessment of paleoelevation.

\section{Introduction}

Stable isotope values of authigenic and pedogenic minerals are a common tool for the reconstruction of paleoelevation changes in mountain ranges (e.g. Poage and Chamberlain, 2001; Rowley and Garzione, 2007, and references therein). $\delta^{18} \mathrm{O}$ and $\delta D$ values of precipitation and meteoric water become more negative with increasing elevation due to rain-out caused by the decrease in temperature and relative humidity, the so-called "altitude effect" (Dansgaard, 1964), a trend that has been recognized in almost all mountain belts of the world (Poage and Chamberlain, 2001). The present day stable oxygen isotope composition of precipitation or meteoric water is well documented in e.g. authigenic carbonates or soil water. This relationship can be used to infer elevation changes of mountain ranges (e.g. Poage and Chamberlain, 2001; Rowley and Garzione, 2007, and references therein). Precipitation and surface water isotopic composition along an altitude gradient provides an isotopic lapse rate that can be used as a reference line for the reconstruction of historical elevation changes. By comparing the reference line with the isotopic values of pedogenic minerals that have formed in the past, such as carbonates, clays, or volcanic glass that, at the time of formation, have formed in equilibrium with surface waters, a paleoelevation record can be obtained. However, there

Published by Copernicus Publications on behalf of the European Geosciences Union. 
are some disadvantages in using this method. For example, the obtained records are generally very smoothed due to the low formation rate of carbonates, and show a millennial signal at best (Rowley and Garzione, 2007). Furthermore, the mineral isotopic composition can be influenced by different source waters and temperature variations during formation (Dettman and Lohmann, 2000; Rowley and Garzione, 2007). Also, diagenesis and recrystallization can modify the original isotopic composition of pedogenic minerals (Morrill and Koch, 2002; Garzione et al., 2004). Thus, further development of paleoelevation proxies is needed to reduce uncertainties in paleoelevation reconstructions, including developing and validating new proxies, and combining these different proxies in multi-proxy applications.

Recently, Jia et al. (2008) explored the suitability of soil $n$-alkane $\delta D$ values as a proxy for paleoelevation as it has been shown previously that hydrogen isotope ratios of leaf wax $n$-alkanes strongly relate to that of environmental water (e.g. Sessions et al., 1999; Sauer et al., 2001; Sachse et al., 2004; Smith and Freeman, 2006; Rao et al., 2009) and that the hydrogen isotopic composition of environmental water depends on altitude (Dansgaard, 1964). Indeed, the $n$-alkane $\delta D$ values for surface soils along the eastern slope of Mt. Gongga (China) record the altitude effect on the precipitation $\delta D$ well, showing a decreasing trend with altitude (Jia et al., 2008 ). Based on the relation of $n$-alkane $\delta D$ with altitude on the Tibetan Plateau, the uplift of this plateau during the late Eocene and early Miocene was recently reconstructed, the result being consistent with a paleoelevation reconstruction based on carbonate $\delta^{18} \mathrm{O}$ (Polissar et al., 2009). An advantage of using $n$-alkanes hydrogen isotope values instead of those of pedogenic minerals, is that elevations can also be determined at sites where no carbonates are present, but where organic material has been preserved. Furthermore, the production of plant lipids is a relatively short-term process compared to the formation and precipitation of minerals, which makes it possible to increase the resolution of the paleoelevation records. Finally, the uncertainties from the temperature effect during mineral formation that has to be taken into account when using mineral isotope values (Poage and Chamberlain, 2001) can be largely avoided by the use $n$-alkane $\delta D$ data, as the apparent isotopic fractionation between water and plant lipids during lipid production is seemingly less temperature dependent than that during carbonate precipitation (Jia et al., 2008). However, a disadvantage of this proxy is that the apparent fractionation may be influenced by physical or vegetation changes along an altitudinal transect, so that soil $n$-alkane $\delta D$ values can only be applied as a paleoelevation proxy when the apparent hydrogen isotope fractionation between precipitation and plant wax $n$-alkanes appears to be independent of elevation, or when changes in apparent fractionation can be reconstructed (Jia et al., 2008).

An alternative method to reconstruct paleoelevation, independent of precipitation, could be the MBT/CBT temperature proxy, which is based on the membrane composi- tion of a yet unknown group of bacteria that occurs ubiquitously in soils worldwide (Weijers et al., 2007c). The membranes of these bacteria are composed of branched glycerol dialkyl glycerol tetraether (GDGT; Fig. 1) lipids, of which the molecular structure can vary in the amount of methyl branches (4 to 6) attached to the alkyl chain, and in the number of cyclopentane moieties (up to 2) (Sinninghe Damsté et al., 2000; Weijers et al., 2006). An empirical study showed that the amount of cyclopentane moieties linearly relates with soil $\mathrm{pH}$, whereas the degree of methylation shows a relation with both soil $\mathrm{pH}$ and annual mean air temperature (MAT; Weijers et al., 2007c). These relations are expressed in two indices, the Cyclisation of Branched Tetraether (CBT) and the Methylation of Branched Tetraether (MBT) index. By analyzing the distribution of branched GDGTs, which can be determined from the same lipid extract as used for $n$-alkane $\delta D$ measurements, and using the combination of the CBT and MBT indices, changes in past environmental conditions can be reconstructed (Weijers et al., 2007a, b; Schouten et al., 2008). Sinninghe Damsté et al. (2008) showed that the distributions of branched GDGTs in surface soils from Mt. Kilimanjaro (Tanzania) change with temperature, and thus with altitude, despite variations in e.g. precipitation or soil type. The temperature lapse rate that was calculated using the MBT/CBT proxy $\left(-6.9 \pm 1.0^{\circ} \mathrm{C} / 1000 \mathrm{~m}\right.$; Sinninghe Damsté et al., 2008), approached the lapse rate that was measured in situ $\left(-5.3^{\circ} \mathrm{C} / 1000 \mathrm{~m}\right.$; Hemp, 2006b). Branched GDGTs are generally well preserved, and have been found in sediments as old as the Palaeocene-Eocene thermal maximum ( $\sim 55 \mathrm{Ma}$; Weijers et al., 2007b), suggesting that they may be suitable components for paleoelevation studies, when applied to paleosols, for example.

Although these paleoelevation proxies seem promising, more studies are needed to examine potential complicating factors. Both soil $n$-alkane $\delta D$ and the MBT/CBT proxy are only indirect recorders of altitude, i.e. through the altitude effect on precipitation $\delta D$ and temperature lapse rate, respectively, and thus other factors besides altitude can potentially affect these proxies. We, therefore, tested these two organicgeochemical proxies on two altitudinal transects to assess their suitability for paleoelevation reconstructions. Soil $n$ alkane $\delta D$ values were measured along the slope of Mt. Kilimanjaro, and the MBT/CBT temperature proxy was applied along the slope of Mt. Gongga. The same samples were previously analyzed for the MBT/CBT proxy of Mt. Kilimanjaro soils and for soil $n$-alkane $\delta D$ analysis of Mt. Gongga by Sinninghe Damsté et al. (2008) and Jia et al. (2008), respectively. 
Ia

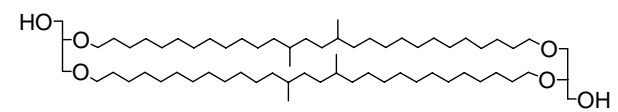

Ib

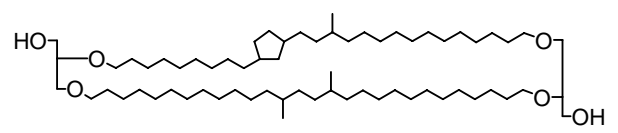

Ic

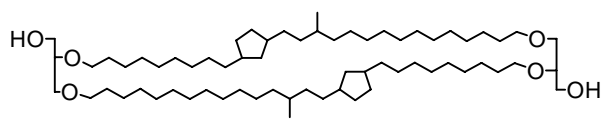

IIa

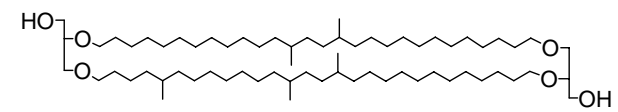

IIb

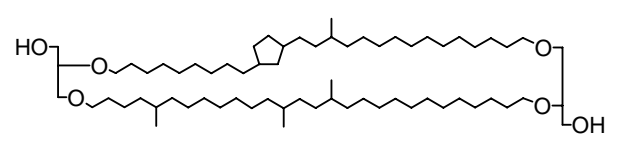

IIC

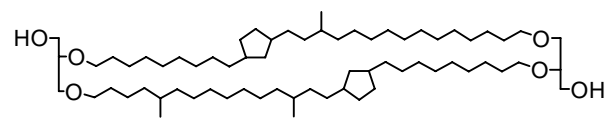

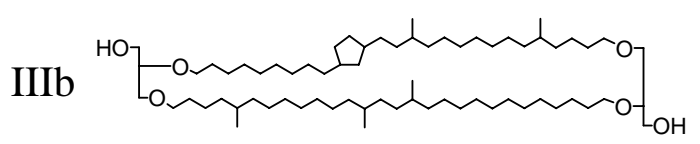

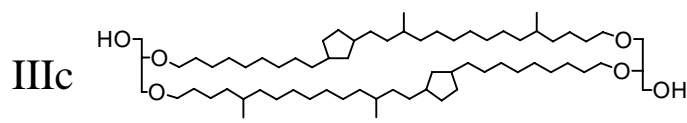

Fig. 1. Molecular structures of branched GDGTs.

\section{Material and methods}

\subsection{Altitudinal transects and soil samples}

Mt. Kilimanjaro is located $300 \mathrm{~km}$ south of the equator in Tanzania on the border with Kenya $\left(3^{\circ} \mathrm{S}, 37^{\circ} \mathrm{E}\right)$. Mt. Kilimanjaro is an ancient volcano, rising from the $700 \mathrm{~m}$ elevated savanna plains to a height of $5895 \mathrm{~m}$, which makes it the highest mountain in Africa. Precipitation and temperature vary with altitude and the degree of exposure to wind from the Indian Ocean. Annual precipitation is higher on the southern slope than on the northern slope.

Due to its location close to the equator Mt. Kilimanjaro experiences two distinct rainy seasons; long rains from March to May, and short, but heavy rains in November and December (Hemp, 2006a, b). Rainfall data for the southern slope show an increase in precipitation from about $1900 \mathrm{~mm} / \mathrm{y}$ at $1400 \mathrm{~m}$ to a maximum of about $2700 \mathrm{~mm} / \mathrm{y}$ at $2200 \mathrm{~m}$ altitude, and then decreasing again towards $50 \%$ of the maximum rainfall at $3000 \mathrm{~m}$, and only $20 \%$ at $4000 \mathrm{~m}$ (Hemp, 2006a, b). MAT is $23.4^{\circ} \mathrm{C}$ at about $800 \mathrm{~m}$, and decreases

linearly upslope with a lapse rate of $-5.3^{\circ} \mathrm{C} / 1000 \mathrm{~m}$ to a MAT of $-7.1^{\circ} \mathrm{C}$ at the top (Hemp, 2006b). Also the vegetation on Mt. Kilimanjaro shows a zonated pattern along the slope (Hemp, 2006a, b). Soil $n$-alkane $\delta D$ analysis were performed on the same soils as used by Sinninghe Damsté et al. (2008), who sampled 16 surface soils between $1700 \mathrm{~m}$ and $3300 \mathrm{~m}$ along the southeastern slope of Mt. Kilimanjaro in September 2006. The soil $\mathrm{pH}$ for this altitudinal transect ranges from 3.8 to 6.6 (Hemp, 2006b).

Mt. Gongga $(7556 \mathrm{~m})$ is located in the Daxue Mountain Range on the eastern side of the Tibetan plateau in Sichuan Province, southwest China $\left(30^{\circ} \mathrm{N}, 102^{\circ} \mathrm{E}\right)$. The eastern slope of Mount Gongga drops $6450 \mathrm{~m}$ in altitude in only $29 \mathrm{~km}$ horizontal distance into the Dadu River valley at $1100 \mathrm{~m}$, the western slope blends into the Tibetan Plateau at 3000-3500 $\mathrm{m}$ (Thomas, 1997). Climate characteristics for the eastern and western side of the mountain are substantially different; the east side is influenced by Pacific air masses, whereas the west side is under influence of the Southwest Monsoon. This results in a relatively cool and humid climate with heavy precipitation on the east side of the mountain, and a drier and warmer climate on the west side. Annual precipitation increases with altitude on both sides, with the major part falling during the hottest summer months (May to October) (Thomas, 1997, 1999). Weather station data show that MAT declines upward from $11.8^{\circ} \mathrm{C}$ at $1600 \mathrm{~m}$ to $3.4^{\circ} \mathrm{C}$ at $3000 \mathrm{~m}$ (Jia et al., 2008). The climatic changes along the altitudinal gradient cause variations in soil and vegetation types, showing a vertical zonated pattern along the slope (Thomas, 1999; Zhong et al., 1999). The soils used for branched GDGT analysis are similar to the ones used in Jia et al. (2008). Our sample set comprises of 36 surface horizons $(0-5 \mathrm{~cm})$ along an altitude gradient from $1180 \mathrm{~m}$ to $3819 \mathrm{~m}$ on the eastern slope of Mt. Gongga, and was sampled in late May 2004. The soils were stored frozen upon arrival in the laboratory in China, and freeze dried before shipping to the laboratory at NIOZ. The $\mathrm{pH}$ of the soils was measured in the laboratory in China in a 1:2.5 soil:water $(\mathrm{w} / \mathrm{v})$ mixture.

\subsection{Soil extractions}

All soils were freeze dried and powdered with mortar and pestle prior to extraction ( 3 times for $5 \mathrm{~min}$ ) with a solvent mixture of dichloromethane (DCM): $\mathrm{MeOH}(9: 1, \mathrm{v} / \mathrm{v})$ using an accelerated solvent extractor (ASE 200, Dionex) at $100^{\circ} \mathrm{C}$ and $7.6 \times 10^{6} \mathrm{~Pa}$. Each total extract was dried using a rotary evaporator under near vacuum. The extracts were dissolved in DCM and passed over a $\mathrm{Na}_{2} \mathrm{SO}_{4}$ column to remove all remaining water, dried again under a $\mathrm{N}_{2}$ flow, and weighed, depending on which $0.1-1.0 \mu \mathrm{g}$ of a $\mathrm{C}_{46}$ GDGT standard was added to the extracts (cf. Huguet et al., 2006). The extracts were separated by passing them over an activated $\mathrm{Al}_{2} \mathrm{O}_{3}$ column using hexane:DCM (9:1, v/v) and DCM:MeOH (1:1, $\mathrm{v} / \mathrm{v})$ to obtain an apolar and polar fraction, respectively. 


\subsubsection{Soil $n$-alkane $\delta D$ analysis}

The apolar fractions were each passed over a small silver nitrate impregnated silica column using hexane to further separate the $n$-alkanes. The $n$-alkane containing fractions were analyzed by gas chromatography (GC) using an Agilent 6890 gas chromatograph with a flame ionization detector using a fused silica capillary column $(25 \mathrm{~m} \times 0.32 \mathrm{~mm})$ coated with CP Sil-5 (film thickness $=0.12 \mu \mathrm{m}$ ) with helium as carrier gas. The fractions were dissolved in $n$-hexane, and injected on-column at $70^{\circ} \mathrm{C}$. The oven was programmed to subsequently increase the temperature to $130^{\circ} \mathrm{C}$ with $20^{\circ} \mathrm{C} / \mathrm{min}$, and then with $4{ }^{\circ} \mathrm{C} / \mathrm{min}$ to $320^{\circ} \mathrm{C}$ at which it was held isothermal for $10 \mathrm{~min}$. Compound-specific hydrogen isotopic compositions of the $n$-alkanes were determined by GC/thermal conversion/isotope ratio monitoring mass spectrometer using a Thermo Electron DELTAPlus XL mass spectrometer. GC conditions were similar to conditions for GC analysis except that the film thickness of the CPSil 5 column was $0.4 \mu \mathrm{m}$ and that a constant flow of $\mathrm{He}$ was used at $1.5 \mathrm{ml} / \mathrm{min}$. Compounds were pyrolyzed at $1450^{\circ} \mathrm{C}$ in an empty ceramic tube, which was preactivated by a methane flow of $0.5 \mathrm{ml} / \mathrm{min}$ for $5 \mathrm{~min}$. $\mathrm{H}_{3}^{+}$-factors were determined daily on the isotope mass spectrometer and decreased slowly from 8.5 to 6 over a 6 week period. $\mathrm{H}_{2}$ gas with known isotopic composition was used as reference and a mixture of $\mathrm{C}_{16}-\mathrm{C}_{32} n$-alkanes of known isotopic composition (ranging from $-42 \%$ o to $-256 \%$ vs. VSMOW) was used to monitor the performance of the system. The average offsets between the measured hydrogen isotopic composition of the $\mathrm{C}_{16}-\mathrm{C}_{32}$ $n$-alkanes and their values determined off-line were generally $5 \%$ or less. Analyses were done at least in duplicate and the reproducibility was always better than $7 \%$ o. A squalane standard was co-injected with every sample and its average value was $-170.6 \pm 3.5 \%$, which compared favorably with its off-line determined value of $-170 \%$.

\subsubsection{Branched GDGT analysis}

The polar fractions, containing the branched GDGTs, were dried under $\mathrm{N}_{2}$, ultrasonically dissolved in a hexane:isopropanol (99:1, v/v) mixture, and filtered over a $0.45 \mu \mathrm{m}$ PTFE filter. All polar fractions were concentrated to about $3 \mathrm{mg} / \mathrm{ml}$ prior to analysis by high performance liquid chromatography/atmospheric pressure chemical ionization-mass spectrometry (HPLC/APCI-MS) on an Agilent 1100 series LC/MSD SL according to Schouten et al. (2007), with minor modifications. Briefly, separation of the branched GDGTs was achieved on an Alltech Prevail Cyano column $(150 \mathrm{~mm} \times 2.1 \mathrm{~mm} ; 3 \mu \mathrm{m})$. The compounds were eluted isocratically with $90 \%$ A and $10 \%$ B for 5 min (flow rate $0.2 \mathrm{ml} / \mathrm{min}$ ), and then with a linear gradient to $16 \%$ $\mathrm{B}$ for $34 \mathrm{~min}$, where $\mathrm{A}=$ hexane and $\mathrm{B}=$ hexane:isopropanol $(9: 1, \mathrm{v} / \mathrm{v})$. For all samples, the injection volume was $10 \mu 1$. Selective ion monitoring of the $[\mathrm{M}+\mathrm{H}]^{+}$was used to detect and quantify the different GDGTs, and absolute quantification of each compound was achieved by calculating the area of its corresponding peak in the chromatogram, comparing it with the peak area of the internal standard, and correcting it for the different response factors (cf. Huguet et al., 2006).

The CBT and MBT indices were calculated according to the following equations:

$$
\begin{aligned}
& \mathrm{CBT}=-\log \left(\frac{[\mathrm{Ib}+\mathrm{II} b]}{[\mathrm{Ia}+\mathrm{IIa}]}\right) \\
& \mathrm{MBT}=\frac{[\mathrm{Ia}+\mathrm{Ib}+\mathrm{Ic}]}{[\mathrm{Ia}+\mathrm{Ib}+\mathrm{Ic}+\mathrm{IIa}+\mathrm{II} b+\mathrm{IIc}+\mathrm{III} \mathrm{a}+\mathrm{III} b+\mathrm{IIIc}]}
\end{aligned}
$$

Roman numerals refer to the structures in Fig. 1. The soil $\mathrm{pH}$ and MAT were calculated using the empirical equations based on the global calibration set given by (Weijers et al., 2007c):

$$
\begin{aligned}
& \mathrm{CBT}=3.33-0.38 \times \mathrm{pH} \\
& \mathrm{MBT}=0.122+0.187 \times \mathrm{CBT}+0.020 \times \mathrm{MAT}
\end{aligned}
$$

Average errors based on duplicate analysis for MBT and CBT on 12 samples are 0.003 and 0.007 , respectively.

\section{Results and discussion}

\subsection{Soil $n$-alkane $\delta D$ values along Mt. Kilimanjaro}

Soil $n$-alkanes along Mt. Kilimanjaro range from $\mathrm{C}_{27}$ to $\mathrm{C}_{35}$, and exhibit an odd-over-even predominance, as is represented by the carbon preference index (CPI) of the $n$-alkanes, which ranges from 5.5 to 15.8. The average chain length (ACL) of the $\mathrm{C}_{27}-\mathrm{C}_{35} n$-alkanes along the analyzed transect varies between 30.2 and 32.0. $\mathrm{C}_{29}, \mathrm{C}_{31}$, and $\mathrm{C}_{33} n$ alkanes are most abundant in the soils, and their hydrogen isotope values range from $-154 \%$ o to $-126 \%$ o for the $\mathrm{C}_{29}$, from $-149 \%$ o to $-113 \%$ or the $\mathrm{C}_{31}$, and from $-144 \%$ o to $-116 \%$ or the $\mathrm{C}_{33} n$-alkane (Table 1 ).

To test if the $\delta D$ of higher plant $n$-alkanes on Mt. Kilimanjaro records precipitation $\delta D\left(\delta D_{p}\right)$, one would ideally use directly measured $\delta D_{p}$ values. However, for the altitudes that our soil samples were derived from, these data were not available. We therefore used modeled $\delta D_{p}$ values according to Bowen and Revenaugh (2003) and Bowen (2009) (Table 1), noting that only a low density of stations feed the model database for this region. Following the approach of Jia et al. (2008), we plotted the weighed mean of the $\delta D$ of the most common $n$-alkanes $\left(\mathrm{C}_{29}, \mathrm{C}_{31}\right.$ and $\left.\mathrm{C}_{33} ; \delta D_{\text {wax }}\right)$ against modeled $\delta D_{p}$ and altitude (Fig. 2a, b). This shows that $\delta D_{\text {wax }}$ values do not strongly correlate with the modeled $\delta D_{p}$, as was found for Mt. Gongga (Jia et al., 2008). 

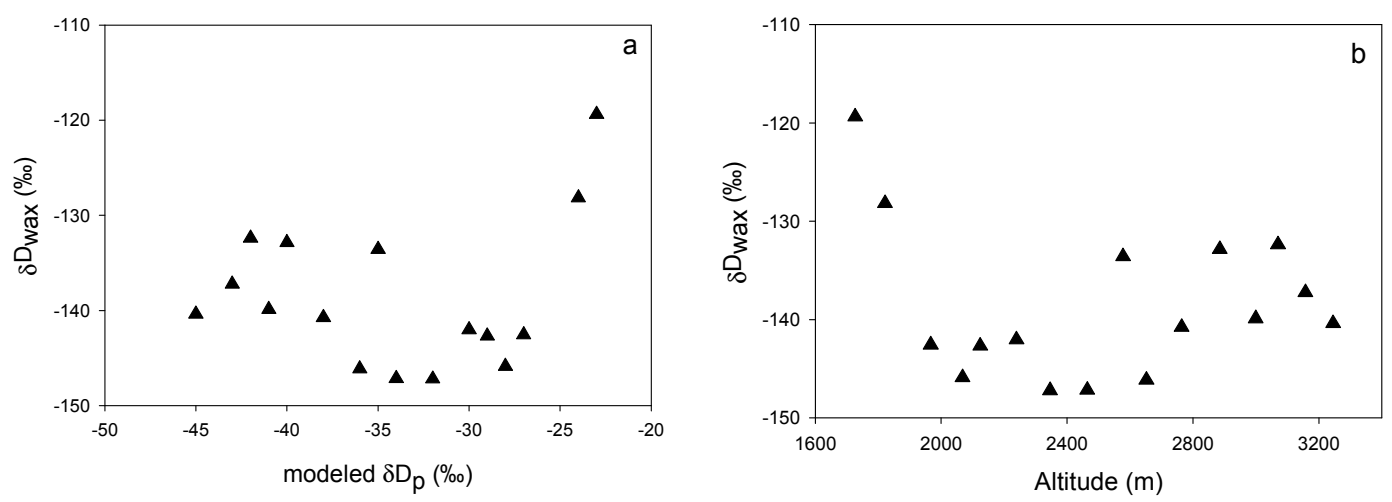

Fig. 2. Relations of $\delta D_{\text {wax }}$ with (a) modeled $\delta D_{p}$ and (b) altitude in $\%$ versus VSMOW along the southeastern slope of Mt. Kilimanjaro.

Table 1. $\delta D$ values for soil $n$-alkanes and modeled $\delta D$ values of precipitation (\%o) along the southeastern slope of Mt. Kilimanjaro.

\begin{tabular}{lrrrrr}
\hline Altitude (m) & \multicolumn{5}{c}{ Soil $n$-alkane } \\
& $\delta D_{\mathrm{C} 29} \pm \mathrm{SD}^{\mathrm{a}}$ & $\delta D_{\mathrm{C} 31} \pm \mathrm{SD}$ & $\delta D_{\mathrm{C} 33} \pm \mathrm{SD}$ & $\delta D_{\mathrm{wax}}^{\mathrm{b}}$ & $\delta D_{p}^{\mathrm{c}}$ \\
\hline 1727 & $-114 \pm 6$ & $-118 \pm 12$ & $-129 \pm 6$ & -119.4 & -23 \\
1822 & $-135 \pm 2$ & $-125 \pm 0$ & $-129 \pm 4$ & -128.2 & -24 \\
1967 & $-156 \pm 1$ & $-138 \pm 1$ & $-134 \pm 2$ & -142.6 & -27 \\
2068 & $-152 \pm 0$ & $-144 \pm 2$ & $-137 \pm 2$ & -145.9 & -28 \\
2124 & $-150 \pm 1$ & $-140 \pm 3$ & $-139 \pm 1$ & -142.7 & -29 \\
2239 & $-154 \pm 1$ & $-136 \pm 0$ & $-130 \pm 2$ & -142.0 & -30 \\
2346 & $-152 \pm 1$ & $-144 \pm 1$ & $-144 \pm 1$ & -147.2 & -32 \\
2464 & $-151 \pm 2$ & $-147 \pm 1$ & $-140 \pm 1$ & -147.2 & -34 \\
2578 & $-139 \pm 3$ & $-134 \pm 1$ & $-118 \pm 1$ & -133.6 & -35 \\
2652 & $-144 \pm 3$ & $-149 \pm 1$ & $-137 \pm 3$ & -146.1 & -36 \\
2764 & $-149 \pm 4$ & $-143 \pm 1$ & $-121 \pm 0$ & -140.8 & -38 \\
2885 & $-138 \pm 2$ & $-136 \pm 2$ & $-125 \pm 2$ & -132.9 & -40 \\
2999 & $-144 \pm 4$ & $-143 \pm 1$ & $-135 \pm 0$ & -139.9 & -41 \\
3070 & $-154 \pm 3$ & $-133 \pm 4$ & $-124 \pm 5$ & -132.4 & -42 \\
3157 & $-143 \pm 2$ & $-138 \pm 3$ & $-132 \pm 4$ & -137.2 & -43 \\
3245 & $-151 \pm 0$ & $-143 \pm 1$ & $-134 \pm 1$ & -140.4 & -45 \\
\hline
\end{tabular}

a Standard deviation of at least duplicate measurements.

${ }^{b}$ Weighed means of $\mathrm{C}_{29}, \mathrm{C}_{31}$, and $\mathrm{C}_{33} n$-alkanes.

${ }^{c}$ Modeled precipitation $\delta D$ along Mt. Kilimanjaro according to Bowen and Revenaugh (2003) and Bowen (2009).

There are several environmental parameters that can potentially have influenced the isotopic values of the $n$-alkanes or precipitation, and may thus explain the absence of the linear relation with altitude. Soil $n$-alkane isotopic values may for example have been influenced by changes in vegetation type (Rommerskirchen et al., 2006), along the slope. However, the absent relation is most likely to be explained by the "amount effect", and has been observed in tropical regions before, when the isotopic composition of precipitation is not only related to the condensation temperature, but mainly controlled by local rainout (Rozanski et al., 1992; Rozanski and Araguás Araguás, 1995). The "amount effect" results in more depleted $\delta D_{p}$ values with higher amounts of rainfall and/or harder rains, and at Mt. Kilimanjaro, the amount of precipitation and relative humidity are at their highest in the middle montane zone (Hemp, 2006a, b), exactly where $\delta D_{\text {wax }}$ values are most depleted (Fig. $2 b$ ). At the midslope high precipitation belt, the actual $\delta D_{p}$ may have shifted to much lower values than the modeled $\delta D_{p}$ due to the "amount effect". Indeed, along the western slope of Mt. Kenya $\left(0^{\circ} \mathrm{S}\right.$, $37^{\circ} \mathrm{E}$ ), which has a climate similar to Mt. Kilimanjaro, precipitation and lake water $\delta D$ values were also found to be influenced by the "amount effect" rather than by the "altitude effect" (Rietti-Shati et al., 2000). However, due to the lack of measured source water $\delta D$ data, we can only speculate about the factors which can explain the absent linear relation. 


\subsection{Branched GDGTs along Mt. Gongga}

Branched GDGTs were found in all analyzed surface soils of Mt. Gongga. Their concentrations vary between 0.01 and $5.3 \mu \mathrm{g} / \mathrm{g}$ dry weight (dwt) soil (Table 2). The distribution of branched GDGTs varies substantially, as is reflected by the CBT and MBT indices, which were calculated according to Eq. (1) and Eq. (2), respectively (Table 2). The CBT index for the soils ranges from 0.03 to 1.65 . At $1515 \mathrm{~m}$ and $1610 \mathrm{~m}$, CBT could not be calculated due to the absence, or too low abundance of branched GDGTs with a cyclopentane moiety (i.e. Ib and IIb; Fig. 1). MBT values vary between 0.21 and 0.83 . The highest values are found at the lower part of the slope in the shrub and grass vegetation zone (1000-1600 m), above which the MBT values are lower, and remain relatively constant along the rest of the slope.

The variable $\mathrm{CBT}$ and $\mathrm{MBT}$ values along the altitude gradient suggest that the branched GDGT distribution is influenced by changes in MAT and soil $\mathrm{pH}$. The CBT index shows a linear relation with the measured soil $\mathrm{pH}\left(r^{2}=0.72\right.$, $n=34$; Fig. 3 ), and this relation is not significantly different from the global CBT-pH relationship reported by Weijers et al. (2007c), neither for the slope (homogeneity of slopes test: $d f=1,144, F=0.01, P=0.92$ ), nor for the intercept (ANCOVA: $d f=1,145, F=0.36, P=0.55)$. A comparison of the calculated soil pH, derived from the CBT index and Eq. (3), and the measured soil $\mathrm{pH}$, varying from 7.9 at the lower slope to 4.4 at higher elevation (Table 2), shows no significant differences (paired t-test: $t(33)=-0.072, P=0.94)$, suggesting that changes in soil $\mathrm{pH}$ indeed influence the distribution of branched GDGTs, and that the CBT index is a suitable tool to detect those changes.

MAT values along the slope were calculated based on the MBT and CBT indices and Eq. (4). MBT/CBT-derived MATs range from $20.9^{\circ} \mathrm{C}$ at the lower slope $(1220 \mathrm{~m})$ to $-3.1^{\circ} \mathrm{C}$ at the upper slope $(3209 \mathrm{~m})$, and show a linear decrease with altitude $\left(r^{2}=0.55, n=34\right.$; Fig. 4$)$. The temperature lapse rate based on the MBT/CBT-derived MAT values is $-5.9 \pm 0.9^{\circ} \mathrm{C} / 1000 \mathrm{~m}$ for Mt. Gongga. This calculated lapse rate is identical to the temperature lapse rate of $-6.0^{\circ} \mathrm{C} / 1000 \mathrm{~m}$ based on the weather station data. Nevertheless, there is a relatively large scatter in the MBT/CBTderived MAT relationship with altitude, larger than observed for Mt. Kilimanjaro (Sinninghe Damsté et al., 2008). Possibly, other factors than $\mathrm{pH}$ or temperature, like soil type or the length of the growing season, have caused the relatively large scatter for this altitude gradient. This suggests that estimations of temperature are associated with relatively large uncertainties, which makes this proxy less suitable for accurate paleoelevation studies in this area.

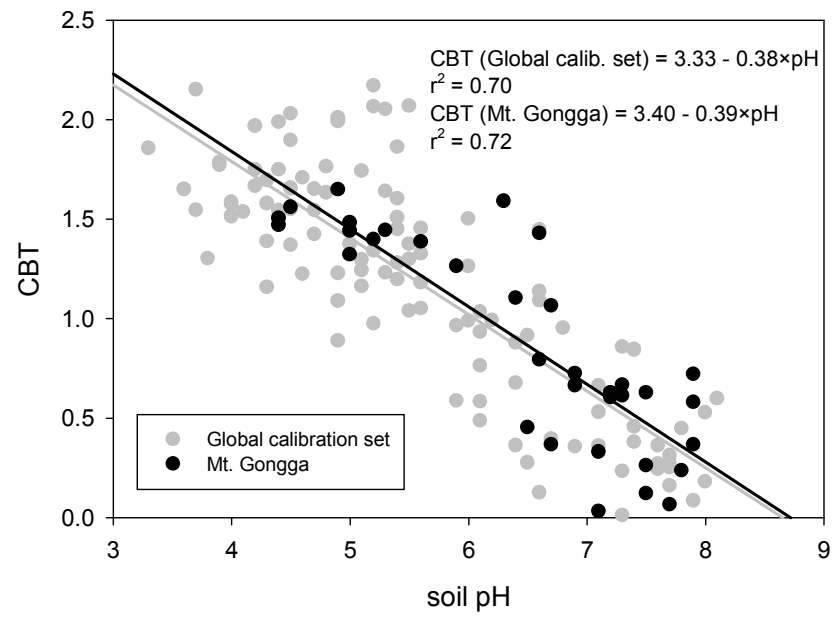

Fig. 3. Cross plot of the CBT index vs. measured soil $\mathrm{pH}$ for the soils along the eastern slope of Mt. Gongga (black) and for the global soil calibration set of Weijers et al. (2007c) (grey).

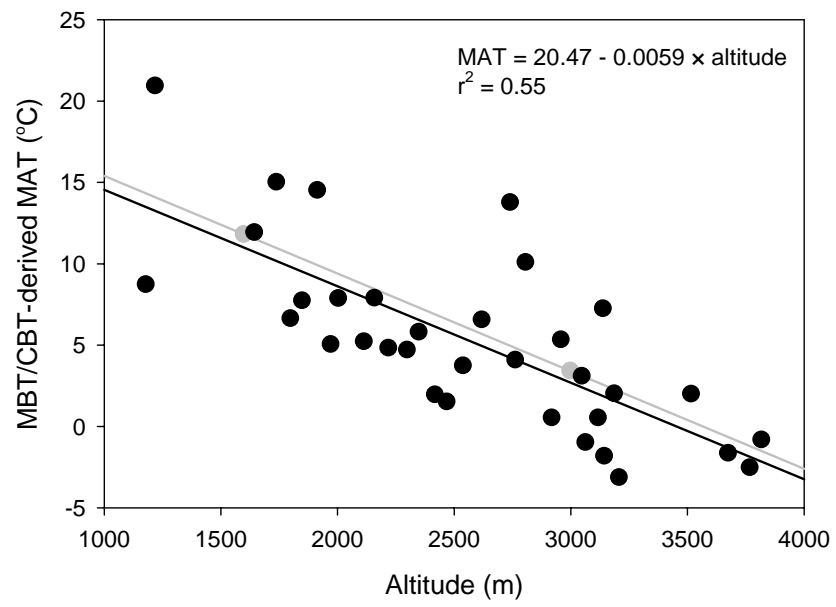

Fig. 4. Relations of MBT/CBT-derived MATs (black) and weather station data (grey) with altitude along the eastern slope of Mt. Gongga.

\section{Implications and conclusions}

Our results for the $\delta D_{\text {wax }}$ in soils of Mt. Kilimanjaro suggest that caution should be taken in deriving a reference record for paleoelevation reconstructions based on $n$-alkane $\delta D$ values. Possibly, the relatively high amounts of precipitation in the middle montane belt cause a relative depletion in $\mathrm{D}$ of the plant wax $n$-alkanes, and therefore mask the relation between $\delta D_{\text {wax }}$ and altitude $\left(r^{2}=0.03, n=16\right.$; Fig. $\left.2 \mathrm{~b}\right)$ required for a paleoelevation proxy. Indeed, the calculated " $\delta D$-lapse rate" along Mt. Kilimanjaro would be $2.6 \pm 4.2 \%$ o $1000 \mathrm{~m}$, suggesting that, due to both the large error and the absence of a linear relation, $\delta D_{\text {wax }}$ is unlikely to be useful at this location.

In contrast, the MBT/CBT temperature proxy at Mt. Kilimanjaro, which is not influenced by precipitation, shows 
Table 2. Soil $\mathrm{pH}$, branched GDGT concentrations, MBT/CBT values, CBT-derived $\mathrm{pH}$, and MBT/CBT-derived MAT for soils along the eastern slope of Mt. Gongga.

\begin{tabular}{|c|c|c|c|c|c|c|}
\hline $\begin{array}{l}\text { Altitude } \\
(\mathrm{m})\end{array}$ & $\begin{array}{r}\text { Soil } \\
\mathrm{pH}\end{array}$ & $\begin{array}{r}\text { Total branched GDGTs } \\
(\mu \mathrm{g} / \mathrm{g} \text { dry weight soil) }\end{array}$ & CBT & MBT & $\begin{array}{r}\text { CBT-derived } \\
\mathrm{pH}\end{array}$ & $\begin{array}{r}\text { MBT/CBT-derived } \\
\text { MAT }\left({ }^{\circ} \mathrm{C}\right)\end{array}$ \\
\hline 1180 & 7.9 & 0.01 & 0.72 & 0.43 & 6.9 & 8.7 \\
\hline 1220 & 7.3 & 0.14 & 0.61 & 0.65 & 7.2 & 20.9 \\
\hline 1515 & n.d. ${ }^{\mathrm{a}}$ & 0.62 & - b & 0.83 & - & - \\
\hline 1610 & 7.8 & 0.01 & - & 0.25 & - & - \\
\hline 1645 & 7.5 & 0.42 & 0.12 & 0.38 & 8.4 & 11.9 \\
\hline 1740 & 6.7 & 0.01 & 0.37 & 0.49 & 7.8 & 15.0 \\
\hline 1800 & 7.1 & 0.72 & 0.33 & 0.32 & 7.9 & 6.6 \\
\hline 1850 & 7.5 & 0.15 & 0.26 & 0.33 & 8.1 & 7.7 \\
\hline 1915 & 6.9 & 1.17 & 0.72 & 0.55 & 6.9 & 14.5 \\
\hline 1973 & 7.7 & 2.69 & 0.06 & 0.23 & 8.6 & 5.0 \\
\hline 2005 & 7.5 & 1.30 & 0.63 & 0.40 & 7.1 & 7.9 \\
\hline 2115 & 7.1 & 0.46 & 0.03 & 0.23 & 8.7 & 5.2 \\
\hline 2160 & 7.9 & 0.51 & 0.36 & 0.35 & 7.8 & 7.9 \\
\hline 2220 & 6.6 & 0.26 & 0.79 & 0.37 & 6.7 & 4.8 \\
\hline 2300 & 6.7 & 0.86 & 1.06 & 0.41 & 6.0 & 4.7 \\
\hline 2350 & 6.9 & 1.28 & 0.66 & 0.36 & 7.0 & 5.8 \\
\hline 2420 & 7.2 & 0.47 & 0.63 & 0.28 & 7.1 & 1.9 \\
\hline 2470 & 7.9 & 0.66 & 0.58 & 0.26 & 7.2 & 1.5 \\
\hline 2540 & 7.8 & 0.13 & 0.23 & 0.24 & 8.1 & 3.7 \\
\hline 2620 & 6.5 & 0.16 & 0.45 & 0.34 & 7.6 & 6.5 \\
\hline 2742 & 4.4 & 2.86 & 1.47 & 0.67 & 4.9 & 13.8 \\
\hline 2764 & 5.9 & 2.68 & 1.26 & 0.44 & 5.4 & 4.1 \\
\hline 2808 & 5.0 & 5.29 & 1.32 & 0.57 & 5.3 & 10.1 \\
\hline 2920 & 5.2 & 1.22 & 1.40 & 0.39 & 5.1 & 0.5 \\
\hline 2960 & 7.2 & 0.67 & 0.60 & 0.34 & 7.2 & 5.3 \\
\hline 3049 & 4.5 & 1.96 & 1.56 & 0.48 & 4.7 & 3.1 \\
\hline 3065 & 6.4 & 0.34 & 1.10 & 0.31 & 5.9 & -1.0 \\
\hline 3119 & 5.6 & 0.49 & 1.38 & 0.39 & 5.1 & 0.5 \\
\hline 3140 & 4.9 & 0.61 & 1.65 & 0.57 & 4.4 & 7.2 \\
\hline 3145 & 7.3 & 0.11 & 0.67 & 0.21 & 7.0 & -1.8 \\
\hline 3188 & 5.3 & 0.49 & 1.44 & 0.43 & 5.0 & 2.0 \\
\hline 3209 & 5.0 & 0.24 & 1.44 & 0.33 & 5.0 & -3.1 \\
\hline 3518 & 4.4 & 4.69 & 1.50 & 0.44 & 4.8 & 2.0 \\
\hline 3676 & 6.6 & 0.33 & 1.43 & 0.36 & 5.0 & -1.7 \\
\hline 3769 & 6.3 & 1.93 & 1.59 & 0.37 & 4.6 & -2.5 \\
\hline 3819 & 5.0 & 1.94 & 1.48 & 0.38 & 4.9 & -0.8 \\
\hline
\end{tabular}

a not determined; ${ }^{b}$ could not be calculated'

a good linear relation with altitude $\left(r^{2}=0.77, n=16\right.$; Sinninghe Damsté et al., 2008), although the MBT/CBT-based temperature lapse rate $\left(-6.9 \pm 1.0^{\circ} \mathrm{C} / 1000 \mathrm{~m}\right)$ is somewhat higher than the measured lapse rate $\left(-5.3 \pm 0.1^{\circ} \mathrm{C} / 1000 \mathrm{~m}\right.$; Hemp, 2006a, b). In case of Mt. Gongga, $n$-alkane $\delta D$ values relate linearly with altitude (Jia et al., 2008), thereby providing a fairly good proxy to estimate " $\delta D$-lapse rate" $(17.7 \pm 1.7 \%$ o/1000 m). Although the MBT/CBT-based MAT estimates also show a linear relation with altitude and provide a temperature lapse rate that resembles the measured lapse rate (respectively $-5.9^{\circ} \mathrm{C}$ and $-6.0^{\circ} \mathrm{C} / 1000 \mathrm{~m}$ ), there is a large degree of scatter in this correlation.
Thus, it seems that for the two studied mountains, neither potential paleoelevation proxy is working perfectly. However, the combination of soil $n$-alkane $\delta D$ values and the MBT/CBT temperature proxy may be a suitable alternative for the more traditional $\delta^{18} \mathrm{O}$ based paleoelevation reconstructions. The combination of both organic-geochemical proxies is easily made, as they can be determined from the same lipid extract, yet they are based on fundamentally different principles. Similar paleoelevation estimates from both proxies would yield increased confidence. Compared to the more traditional $\delta^{18} \mathrm{O}$ based reconstructions, it should then be possible to obtain higher resolution records, as plant 
growth and adaptations in bacterial cell membranes are relatively fast processes. Furthermore, branched GDGTs and $n$-alkanes are relatively more resistant to diagenesis than soil carbonate, and paleoelevation studies may then also be performed in areas where no carbonates or other minerals are present.

Acknowledgements. We thank Dirk Verschuren (University of Gent, Belgium) for logistic support and helpful discussions, and A. Hemp (University of Bayreuth, Germany) for hospitality and guidance during fieldwork in Tanzania. We thank two anonymous reviewers for their comments which improved this manuscript. This work was partially performed as part of the ESF Euroclimate project Challacea, financially supported by the Dutch Organization for Scientific Research (NWO). MvdM was funded by the Dutch Organization for Scientific Research (NWO), Earth and Life Sciences (ALW), through grant No. 818.07.022 This is publication number DW-2009-5002 of the Darwin Center for Biogeosciences, which partially funded this project.

Edited by: J. Bijma

\section{References}

Bowen, G. J. and Revenaugh, J.: Interpolating the isotopic composition of modern meteoric precipitation, Water Resour. Res., 39, SWC9-1-SWC9-13, 2003.

Bowen, G. J.: The Online Isotopes in Precipitation Calculator, version 2.2, online available at: http://www.waterisotopes.org, last access: August 2009.

Dansgaard, W.: Stable isotopes in precipitation. Tellus XVI, 436468, 1964.

Dettman, D. L. and Lohmann, K. C.: Oxygen isotope evidence for high-altitude snow in the Laramide Rocky Mountains of North America during the Late Cretaceous and Paleogene, Geology, 28, 243-246, 2000.

Garzione, C. N., Dettman, D. L., and Horton, B. K.: Carbonate oxygen isotope paleoaltimetry: evaluating the effect of diagenesis on paleoelevation estimates for the Tibetan plateau, Palaeogeogr. Palaeocl., 212, 119-140, 2004.

Hemp, A.: Continuum or zonation? Altitudinal gradients in the forest vegetation of Mt. Kilimanjaro, Plant Ecol., 184, 27-42, 2006a.

Hemp, A.: Vegetation of Kilimanjaro: hidden endemics and missing bamboo, Afr. J. Ecol., 44, 305-328, 2006b.

Huguet, C., Hopmans, E. C., Febo-Ayala, W., Thompson, D. H., Sinninghe Damsté, J. S., and Schouten, S.: An improved method to determine the absolute abundance of glycerol dibiphytanyl glycerol tetraether lipids, Org. Geochem., 37, 1036-1041, 2006.

Jia, G., Wei, K., Chen, F., and Peng, P.: Soil $n$-alkane $\delta D$ vs. altitude gradients along Mount Gongga, China, Geochim. Cosmochim. Acta, 72, 5165-5174, 2008.

Morrill, C. and Koch, P. L.: Elevation or alteration? Evaluation of isotopic constraints on paleoaltitudes surrounding the Eocene Green River Basin, Geology, 30, 151-154, 2002.

Poage, M. A. and Chamberlain, C. P.: Empirical relationships between elevation and the stable isotope composition of precipitation and surface waters: Considerations for studies of paleoelevation change, Am. J. Sci., 301, 1-15, 2001.
Polissar, P. J., Freeman, K. H., Rowley, D. B., McInerney, F. A., and Curry, B. S.: Paleoaltimetry of the Tibetan Plateau from $D / H$ ratios of lipid biomarkers, Earth Planet. Sci. Lett., 287, 64-76, 2009.

Rao, Z., Zhu, Z., Jia, G., Henderson, A. C. G., Xue, Q., and Wang, S.: Compound specific $\delta D$ values of long chain $n$-alkanes derived from terrestrial higher plants are indicative of the $\delta D$ of meteoric waters: Evidence from surface soils in eastern China, Org. Geochem., 40, 922-930, 2009.

Rietti-Shati, M., Yam, R., Karlen, W., and Shemesh, A.: Stable isotope composition of tropical high-altitude fresh-waters on Mt. Kenya, Equatorial East Arfica, Chem. Geol., 166, 341-350, 2000.

Rommerskirchen, F., Plader, A., Eglinton, G., Chikaraishi, Y., and Rullkötter, J.: Chemotaxonomic significance of distribution and stable carbon isotopic composition of long-chain alkanes and alkan-1-ols in $\mathrm{C}_{4}$ grass waxes, Org. Geochem., 37, 1303-1332, 2006.

Rowley, D. B. and Garzione, C. N.: Stable isotope-based paleoaltimetry, Annu. Rev. Earth Planet. Sci., 35, 463-508, 2007.

Rozanski, K. and Araguás Araguás, L.: Spatial and temporal variability of stable isotope composition of precipitation over the south american continent, Bulletin de l'Institut Français d'Études Andines, 24, 379-390, 1995.

Rozanski, K., Araguás-Araguás, L., and Gonfiantini, R.: Relation between long-term trends of O-18 isotope composition of precipitation and climate, Science, 258, 981-985, 1992.

Sachse, D., Radke, J., and Gleixner, G.: Hydrogen isotope ratios of recent lacustrine sedimentary $n$-alkanes record modern climate variability, Geochim. Cosmochim. Acta, 68, 4877-4889, 2004.

Sauer, P. E., Eglinton, T. I., Hayes, J. M., Schimmelmann, A., and Sessions, A. L.: Compound-specific D/H ratios of lipid biomarkers from sediments as a proxy for environmental and climatic conditions, Geochim. Cosmochim. Acta, 65, 213-222, 2001.

Schouten, S., Eldrett, J., Greenwood, D. R., Harding, I., Baas, M., and Sinninghe Damsté, J. S.: Onset of long-term cooling of Greenland near the Eocene-Oligocene boundary as revealed by branched tetraether lipids, Geology, 36, 147-150, 2008.

Schouten, S., Huguet, C., Hopmans, E. C., Kienhuis, M. V. M., and Sinninghe Damsté, J. S.: Analytical methodology for TEX 86 paleothermometry by high-performance liquid chromatography/atmospheric pressure chemical ionization-mass spectrometry, Anal. Chem., 79, 2940-2944, 2007.

Sessions, A. L., Burgoyne, T. W., Schimmelmann, A., and Hayes, J. M.: Fractionation of hydrogen isotopes in lipid biosynthesis, Org. Geochem., 30, 1193-1200, 1999.

Sinninghe Damsté, J. S., Hopmans, E. C., Pancost, R. D., Schouten, S., and Geenevasen, J. A. J.: Newly discovered non-isoprenoid glycerol dialkyl glycerol tetraether lipids in sediments, Chem. Commun., 17, 1683-1684, 2000.

Sinninghe Damsté, J. S., Ossebaar, J., Schouten, S., and Verschuren, D.: Altitudinal shifts in the branched tetraether lipid distribution in soil from Mt. Kilimanjaro (Tanzania): Implications for the MBT/CGT continental palaeothermometer, Org. Geochem., 39, 1072-1076, 2008.

Smith, F. A. and Freeman, K. H.: Influence of physiology and climate on $\delta D$ of leaf wax $n$-alkanes from $\mathrm{C}_{3}$ and $\mathrm{C}_{4}$ grasses, Geochim. Cosmochim. Acta, 70, 1172-1187, 2006.

Thomas, A.: The climate of the Gongga Shan range, Sichuan 
Province, PR China, Arctic Alpine Res., 29, 226-232, 1997.

Thomas, A.: Overview of the geoecology of the Gongga Shan range, Sichuan province, China, Mt. Res. Dev., 19, 17-30, 1999.

Weijers, J. W. H., Schefuß, E., Schouten, S., and Sinninghe Damsté, J. S.: Coupled thermal and hydrological evolution of tropical Africa over the last deglaciation, Science, 315, 1701-1704, $2007 \mathrm{a}$.

Weijers, J. W. H., Schouten, S., Hopmans, E. C., Geenevasen, J. A. J., David, O. R. P., Coleman, J. M., Pancost, R. D., and Sinninghe Damsté, J. S.: Membrane lipids of mesophilic anaerobic bacteria thriving in peats have typical archaeal traits, Environ. Microbiol., 8, 648-657, 2006.
Weijers, J. W. H., Schouten, S., Sluijs, A., Brinkhuis, H., and Sinninghe Damsté, J. S.: Warm arctic continents during the Palaeocene-Eocene thermal maximum, Earth Planet. Sci. Lett., 261, 230-238, 2007b.

Weijers, J. W. H., Schouten, S., van den Donker, J. C., Hopmans, E. C., and Sinninghe Damsté, J. S.: Environmental controls on bacterial tetraether membrane lipid distribution in soils, Geochim. Cosmochim. Acta, 71, 703-713, 2007c.

Zhong, X., Zhang, W., and Luo, J.: The characteristics of the mountain ecosystem and environment in the Gongga Mountain region, AMBIO, 28, 648-654, 1999. 